\title{
Effect of Confined Phonons on Temperature Renormalization of Spectral Characteristics of Quantum Cascade Detector Operating in Far Infrared Range
}

\author{
Ju.O. Seti*, M.V. Tkach, E.Ju. Vereshko
}

Yuriy Fedkovych Chernivtsi National University, 2, Kotsyubinsky St., 58012 Chernivtsi, Ukraine

(Received 14 February 2021; revised manuscript received 15 April 2021; published online 20 April 2021)

\begin{abstract}
The theory of electron-phonon interaction in a separate cascade of the broadband quantum cascade detector operating in far-infrared range is developed within the models of rectangular potentials and position-dependent effective mass, taking into account a nonparabolic shape of the conduction band, for an electron and isotropic dielectric continuum model for optical confined phonons. In the one-phonon approximation, the mass operator of the electron-phonon interaction is analytically calculated. Calculations of the total shifts and decays of cascade electron states are performed within the framework of the temperature Green's function method. Both at cryogenic and at room temperature, an analysis of the electron spectral parameters renormalization due to different mechanisms of the electron-phonon interaction is carried out, depending on the geometric design of the cascade two-well active region. It is shown that, irrespective of the temperature, the shifts caused by the intralevel electron interaction with phonons prevail over the shifts at interlevel interactions. At cryogenic temperature, the decay of the electron ground state is impossible. At a finite temperature, the intralevel interaction of the ground state with phonons causes a greater decay than the interlevel one. The excited states decays caused by the total interlevel interaction prevail over decays due to the intalevel interaction. It is established that with increasing temperature, the confined phonons cause broadening and weak high-energy shift of the detector absorption band, and temperature changes of the physical parameter lead to a significant low-energy shift. This hierarchy of partial contributions explains the experimentally known redshift of the absorption band of quantum cascade detectors with increasing temperature.
\end{abstract}

Keywords: Nanosystem, Electron, Phonon, Quantum cascade detector, Green's function.

DOI: 10.21272/jnep.13(2).02031

PACS numbers: 72.10.Dj, 73.21. - b, 78.20.Bh

\section{INTRODUCTION}

Studies of quantum cascade detectors (QCDs) and their improvement by the methods of band engineering have been going on for almost 20 years since the creation of the first QCD. Modern QCDs [1-6] operating in the infrared (IR) and terahertz ranges are characterized by unique features (minimal dark noise, a wide range of operating temperatures), that makes these nanodevices attractive for spectral analysis, IR imaging, space research etc.

Despite intensive experimental research, a complete and consistent theory of physical processes in QCD cascades is still absent. In most theoretical papers [79], only electron spectral characteristics and photonassisted transport through isotropic and anisotropic elements of nanodevices are investigated. The phonon subsystem is not taken into account in these papers, in spite of the fact that, as is known [10], it provides relaxation of the electron energy in QCD extractors.

The theory of electron-phonon interaction in nanostructures has been developed in some papers, in particular in [11-14], where the Hamiltonian of electronphonon interaction was written in the representation of second quantization over phonon variables and in the coordinate representation over electron ones. This approach makes it possible to calculate the probabilities of electron-phonon assisted quantum transitions and associated physical quantities within the Fermi golden rule, but does not allow one to find out the effect of phonons on the nanostructure spectrum renormalization.
In this paper, within the models of rectangular potentials and effective masses for an electron and a dielectric continuum for confined phonons, the Hamiltonian of electron-phonon interaction in a cascade of far-IR QCD is obtained in the representation of second quantization over all variables of the system. Based on it, using the temperature Green's functions method in the one-phonon approximation, the effect of various mechanisms of electron-phonon interaction on the shifts and decays of the QCD absorption band at both cryogenic and room temperatures is studied.

\section{HAMILTONIAN OF THE ELECTRON- PHONON SYSTEM. MASS OPERATOR}

In the Cartesian coordinates, the multilayer semiconductor nanosystem (Fig. 1) is considered as a separate cascade of QCD. Calculations of the electron energy spectrum and wave functions are carried out in the models of rectangular potentials and positiondependent effective masses, taking into account the conduction band nonparabolic shape

$$
m(E, z)= \begin{cases}m_{w}(E)=m_{w}\left(1+E / E_{g w}\right), & j=1,3,5, \ldots, N \\ m_{b}(E)=m_{b}\left[1-(U-E) / E_{g b}\right], & j=0,2,4, \ldots, N+1\end{cases}
$$

Here, $N$ is the number of cascade layers, $U$ is the barrier height, $m_{w}, m_{b}$ and $E_{g w}, E_{g b}$ are, respectively, the electron effective masses (without nonparabolicity) and energy gaps for the bulk crystals of wells and barriers.

The electron wave functions are represented as

\footnotetext{
*j.seti@chnu.edu.ua
} 


$$
\Psi_{n \vec{k}}(\vec{r})=\frac{e^{i \vec{k} \vec{\rho}}}{\sqrt{S}} \Psi_{n}(z) .
$$

Then, from the Schrödinger equation, both the electron total energies $E_{n \vec{k}}=E_{n}+\hbar^{2} \vec{k}^{2} / 2 m_{n}$ and the onedimensional equation are obtained, from which, taking into account boundary and normalization conditions [15], the functions $\Psi_{n}$ are found in the form:

$$
\Psi_{n}(z)=\left\{\begin{array}{l}
\Psi_{n}^{(j)}(z)=A_{n}^{(j)} e^{\chi_{n} z}+B_{n}^{(j)} e^{-\chi_{n} z}, \quad j=0,2, \ldots, N+1 \\
\Psi_{n}^{(j)}(z)=A_{n}^{(j)} \cos k_{n} z+B_{n}^{(j)} \sin k_{n} z, j=1,3, \ldots, N
\end{array}\right.
$$

where

$$
k_{n}=\hbar^{-1} \sqrt{2 m_{w}\left(E_{n}\right) E_{n}}, \chi_{n}=\hbar^{-1} \sqrt{2 m_{b}\left(E_{n}\right)\left(U-E_{n}\right)} .
$$

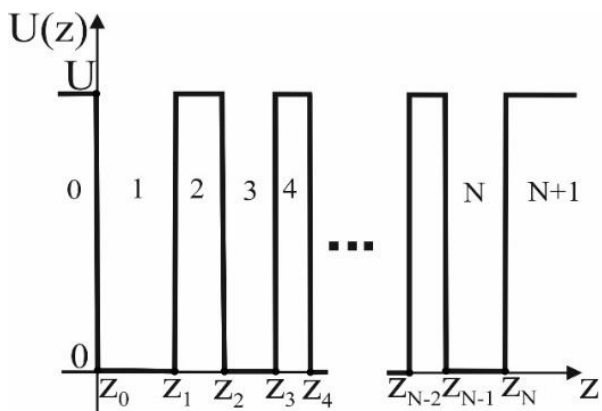

Fig. 1 - Geometric and energy schemes of a QCD multilayer cascade

Now, using quantized electron wave functions

$$
\widehat{\Psi}(\vec{r})=\sum_{n, \bar{k}} \Psi_{n \vec{k}}(\vec{r}) a_{n \vec{k}}
$$

and having passed from the coordinate representation of the electron Hamiltonian to the second quantization representation, we obtain the Hamiltonian of noninteracting electrons in the representation of their occupation numbers

$$
\hat{H}_{e}=\sum_{n \vec{k}} E_{n \bar{k}} a_{n \bar{k}}^{+} a_{n \vec{k}},
$$

where $a_{n \vec{k}}^{+}, a_{n \vec{k}}$ are the fermion creation and annihilation operators.

It is known [16] that in the model of the dielectric continuum with dielectric constants of nanolayers $\varepsilon_{j}(\omega)=\varepsilon_{\infty j}\left(\omega^{2}-\omega_{L j}^{2}\right) /\left(\omega^{2}-\omega_{T j}^{2}\right), j=0, \ldots, N+1$, the potentials of confined (L) phonons satisfy the equations $\varepsilon_{j}(\omega) \nabla^{2} \Phi_{j}(\vec{r})=0$ at $\varepsilon_{j}(\omega)=0, \quad \nabla^{2} \Phi_{j}(\vec{r}) \neq 0$. From the condition $\varepsilon_{j}(\omega)=0$, it follows that the energies of confined phonons $\Omega_{j}=\hbar \omega_{L j}$ coincide with the energies of longitudinally polarized phonons of bulk crystals of nanostructure wells and barriers.

After the expansion of the L-phonon polarization field potential in a two-dimensional Fourier series and its quantization [16], the phonon Hamiltonian is found in the representation of phonon occupation numbers

$$
\hat{H}_{L}=\sum_{j=0}^{N} \sum_{\lambda, \vec{q}} \Omega_{j}\left(b_{j \lambda \vec{q}}^{+} b_{j \lambda \vec{q}}+1 / 2\right),
$$

where $b_{j \lambda \vec{q}}^{+}, b_{j \lambda \vec{q}}$ are the boson creation and annihilation operators.

Therefore, passing from the coordinate representation to the representation of the occupation numbers on the quantized electron wave function (4), the Hamiltonian of electron-phonon interaction is obtained in the representation of second quantization over all variables of the system

$$
\hat{H}_{e-L}=\sum_{j=0}^{N} \sum_{\lambda, \vec{q}} \sum_{n^{\prime}, n, \vec{k}} f_{n^{\prime} n}^{(j)}(\lambda, \vec{q}) a_{n^{\prime} \vec{k}+\vec{q}}^{+} a_{n \bar{k}}\left(b_{j \lambda, \bar{q}}+b_{j \lambda,-\bar{q}}^{+}\right),
$$

where $f_{n^{\prime} n}^{(j)}$ are the electron-phonon binding functions.

The Hamiltonian $\left(\hat{H}=\hat{H}_{e}+\hat{H}_{p h}+\hat{H}_{e-p h}\right)$ of the electron-phonon system in the representation of second quantization, obtained for the case of weak electronphonon coupling, allows [16] to calculate the Fourier images of the electron Green's functions from the Dyson equation $G_{n}(\vec{k}, \hbar \omega)=\left[\hbar \omega-E_{n \vec{k}}-M_{n}(\hbar \omega, \vec{k})\right]^{-1}$ with the mass operator

$$
\begin{gathered}
M_{n}(\hbar \omega, \vec{k})=\sum_{j=0}^{N} \sum_{n^{\prime}} \sum_{\lambda, \vec{q}} f_{n n^{\prime}}^{(j)}(\lambda, q) f_{n^{\prime} n}^{(j)}(\lambda, q) \times \\
\times\left[\frac{1+v_{j}}{\hbar \omega-E_{n^{\prime}}(\vec{k}-\vec{q})-\Omega_{j}+i \eta}+\frac{v_{j}}{\hbar \omega-E_{n^{\prime}}(\vec{k}+\vec{q})+\Omega_{j}+i \eta}\right] .
\end{gathered}
$$

The mass operator takes into account both the processes of emission of confined phonons (the first term) with occupation numbers $v_{j}=\left(e^{\Omega_{j} / k_{B} T}-1\right)^{-1}$ and the processes of their absorption (the second term).

Passing in (8) from the sum over two-dimensional phonon quasimomenta to the integral and using the Dirac relation $\iint(\phi(\vec{q})+i \eta)^{-1} d^{2} \vec{q}=\mathrm{V} . \mathrm{p} \cdot \iint d^{2} \vec{q} / \phi(\vec{q})-i \pi \iint \delta(\phi(\vec{q})) d^{2} \vec{q}$, an exact analytical calculation of the mass operator is performed, which is not presented here due to its cumbersomeness. According to the Green's function theory, the real and imaginary parts of the mass operator determine the shift $\Delta_{n}=\operatorname{Re} M_{n}\left(E_{n}, 0\right)$ and the decay $\gamma_{n}=-2 \operatorname{Im} M_{n}\left(E_{n}, 0\right)$ of the $n$-th electron level, caused by the interaction with confined phonons.

\section{ANALYSIS OF THE EFFECT OF CONFINED PHONONS ON THE SPECTRAL CHARAC- TERISTICS OF THE FAR-IR QCD CASCADE}

The developed theory is applied to study the effect of confined phonons on the spectral characteristics of electron states and absorption band of the far-IR QCD with an optimized geometric design $[17,18]$ at both cryogenic $(T=0 \mathrm{~K})$ and room $(T=300 \mathrm{~K})$ temperatures. The physical parameters of the QCD cascades with GaAs wells $\left(a_{1}=6.5 \mathrm{~nm}, \quad a_{2}=1.7 \mathrm{~nm}, \quad a_{3}=2.3 \mathrm{~nm}\right.$, $\left.a_{4}=3.0 \mathrm{~nm}, \quad a_{5}=4.2 \mathrm{~nm}\right)$ and $\mathrm{Al}_{0.33 \mathrm{Ga}} \mathrm{G}_{67} \mathrm{As}$ barriers $\left(b_{1}=5.65 \mathrm{~nm}, b_{2}=4.2 \mathrm{~nm}, b_{3}=3.1 \mathrm{~nm}, b_{4}=3.1 \mathrm{~nm}\right)$ are as follows: $\mathcal{E}_{\infty w}=9.99, \mathcal{E}_{\infty b}=10.89, \Omega_{L w}=36.25 \mathrm{meV}$, $\Omega_{L b}=40.82 \mathrm{meV}, \quad \Omega_{\mathrm{T} w}=33.29 \mathrm{meV}, \quad \Omega_{T b}=37.12 \mathrm{meV}$, $m_{w}=0.067 m_{e}, \quad m_{b}=0.095 m_{e}, \quad E_{g w}^{T=0 K}=1520 \mathrm{meV}$, 
$E_{g b}^{T=0 K}=1885 \mathrm{meV}, \quad E_{g w}^{T=300 K}=1420 \mathrm{meV}, \quad E_{g b}^{T=300 \mathrm{~K}}=$ $=1788 \mathrm{meV}, U^{T=0 K}=276 \mathrm{meV}, U^{T=300 K}=256 \mathrm{meV}$.

All QCD cascades are identical multi-well nanostructures that contain two parts - an active region and an extractor, which have different functional purposes. Electromagnetic field detection occurs due to electron quantum transitions from the ground state to two excited states of the two-well active region. The electron tunneling between the active regions of adjacent cascades is provided by extractors, the potential wells of which create equidistant electron levels of the "phonon ladder" with distances between them of the order of the phonon energy $\left(\Omega_{L O}^{G a A s}=36.2 \mathrm{meV}\right)$. At the transitions between the "phonon ladder" levels, the electron energy relaxation and phonon emission occur simultaneously.

To reveal the role of confined phonons in the renormalization of the QCD spectral characteristics, the energies $\left(E_{n}\right)$ of the electron operating states $(n=1,5$, 6 ), transitions between which occur due to the absorption of IR electromagnetic field, as well as the energies of the "phonon ladder" states $(n=2,3,4)$, were calculated depending on the potential well width $\left(a_{1}\right)$ at the fixed width of the active region common well $a=a_{1}+a_{2}=8.2 \mathrm{~nm}$

Fig. 2 a shows the dependences of $E_{n}$ on $a_{1}$ at cryogenic $(T=0 \mathrm{~K})$ and room $(T=300 \mathrm{~K})$ temperatures calculated without taking into account the electronphonon interaction, however, taking into account the temperature dependences of both the effective mass and the heights of potential barriers. It can be seen from Fig. 2a that an increase in temperature leads only to low-energy shifts of all electron energies, without changing the regularities of the $E_{n}\left(a_{1}\right)$ dependences.

Fig. 2b-e show the total shifts $\left(\Delta_{n}=\Delta_{n n}+\Delta_{\Sigma n n^{\prime}}\right)$ and decays $\left(\gamma_{n}=\gamma_{n n}+\gamma_{\Sigma} n n^{\prime}\right)$ of all electron states $(n=1-6)$ due to intralevel $\left(\Delta_{n n}, \gamma_{n n}\right)$ and interlevel $\left(\Delta_{\sum n n^{\prime}}=\sum_{n^{\prime} \neq n} \Delta_{n n^{\prime}}\right.$, $\left.\gamma_{\Sigma n n^{\prime}}=\sum n^{\prime} \neq n \gamma_{n n^{\prime}}\right)$ interactions with phonons at both room ( $T=300 \mathrm{~K}$, Fig. $2 \mathrm{~b}, \mathrm{c})$ and cryogenic $(T=0 \mathrm{~K}$, Fig. $2 \mathrm{~d}$, e) temperatures depending on $a_{1}$. It can be seen from Fig. 2b-e that the shifts $\Delta_{n}$ (Fig. 2c, f) and decays $\gamma_{n}$ (Fig. 2b, d) of all electron states are highly nonlinear functions of $a_{1}$, the values of which for various states are commensurate with each other. With an increase in temperature, the absolute values of $\Delta_{n}$ and $\gamma_{n}$ only increase, and their qualitative dependences on $a_{1}$ almost do not change (except for the ground state decay $\gamma_{1}$ ).

We should note that since at cryogenic temperature $(T=0 \mathrm{~K}, v=0)$ the renormalization of the electron spectrum can occur only due to emission of virtual phonons, so at $T=0 \mathrm{~K}$ (Fig. 2 e) the electron-phonon interaction leads to a decrease in the energies of all electron states $\left(\Delta_{n}<0\right)$, regardless of the cascade geometric parameters.

The decay values $\left(\gamma_{n}\right)$ at $T=0 \mathrm{~K}$ are determined by the imaginary part of the mass operator (8), which, through the Dirac identity, contains $\delta$-functions $\delta\left(E_{n}-\right.$ $\left.-E_{n^{\prime}}(q)-\Omega_{j}\right)$ that regulate the fulfillment of the energy conservation law. For the ground state $(n=1)$, the equality $\delta\left(\left[E_{n=1}-E_{n \geq 1}(q)-\Omega_{j}\right]<0\right)=0$ always holds, therefore, at $T=0 \mathrm{~K}$ the decay of the ground state is impossible $\left(\gamma_{1}=0\right)$ under any conditions. Decays of excited states $(n>1)$ occur only at the interlevel interactions (at $E_{n}>E_{n^{\prime}}(q)+\Omega_{j}$ ) with the emission of virtual phonons.
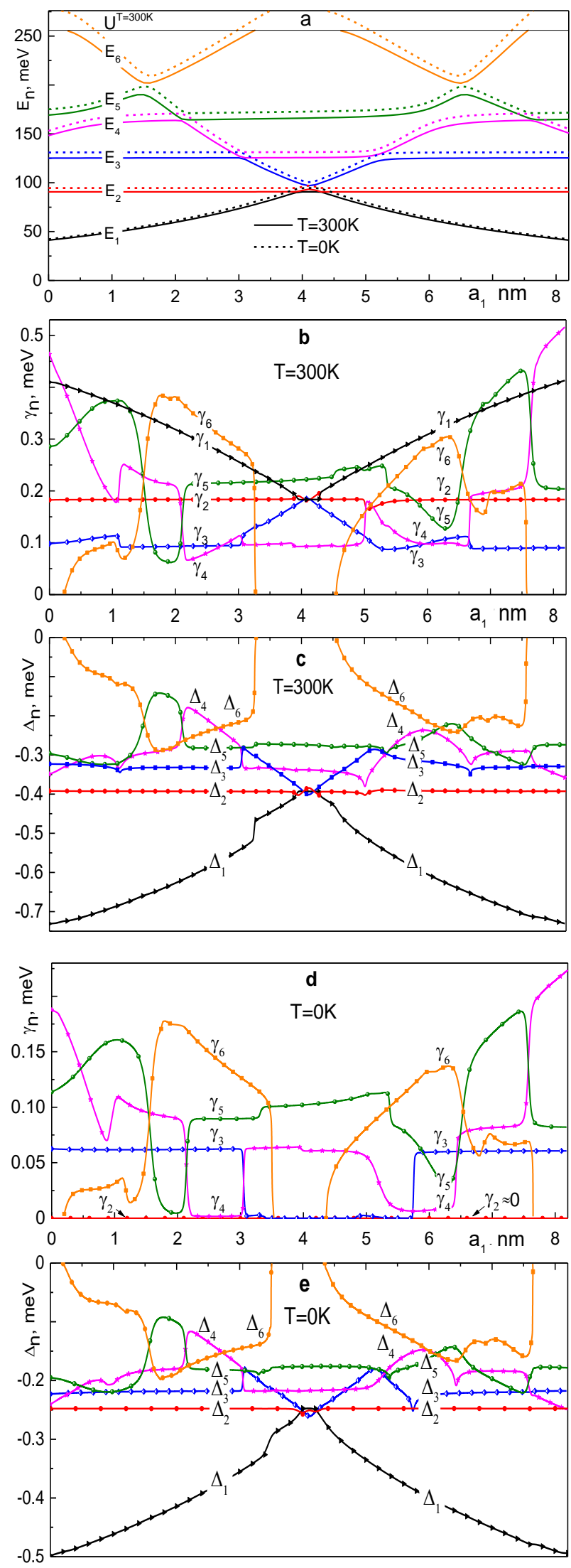

Fig. 2 - Dependences on $a_{1}$ of the electron energies $\left(E_{n}\right)$, as well as the total shifts $\left(\Delta_{n}\right)$ and decays $\left(\gamma_{n}\right)$ of electron states due to the interaction with confined phonons in the cascade of far-IR QCD at room $(T=300 \mathrm{~K})$ and cryogenic $(T=0 \mathrm{~K})$ temperatures 
At a finite temperature $(T \neq 0 \mathrm{~K})$, processes with emission, as well as with the absorption of real phonons, are possible. In this case, $\delta\left(E_{n}-E_{n^{\prime}}(q)+\Omega_{\mathrm{j}}\right) \neq 0$ in the mass operator (8) second term, therefore, all electron states, including the ground one, are characterized by temperature shifts and decays. The shift and decay values are determined by the prevailing mechanisms (interlevel or intralevel) of electron-phonon interaction.
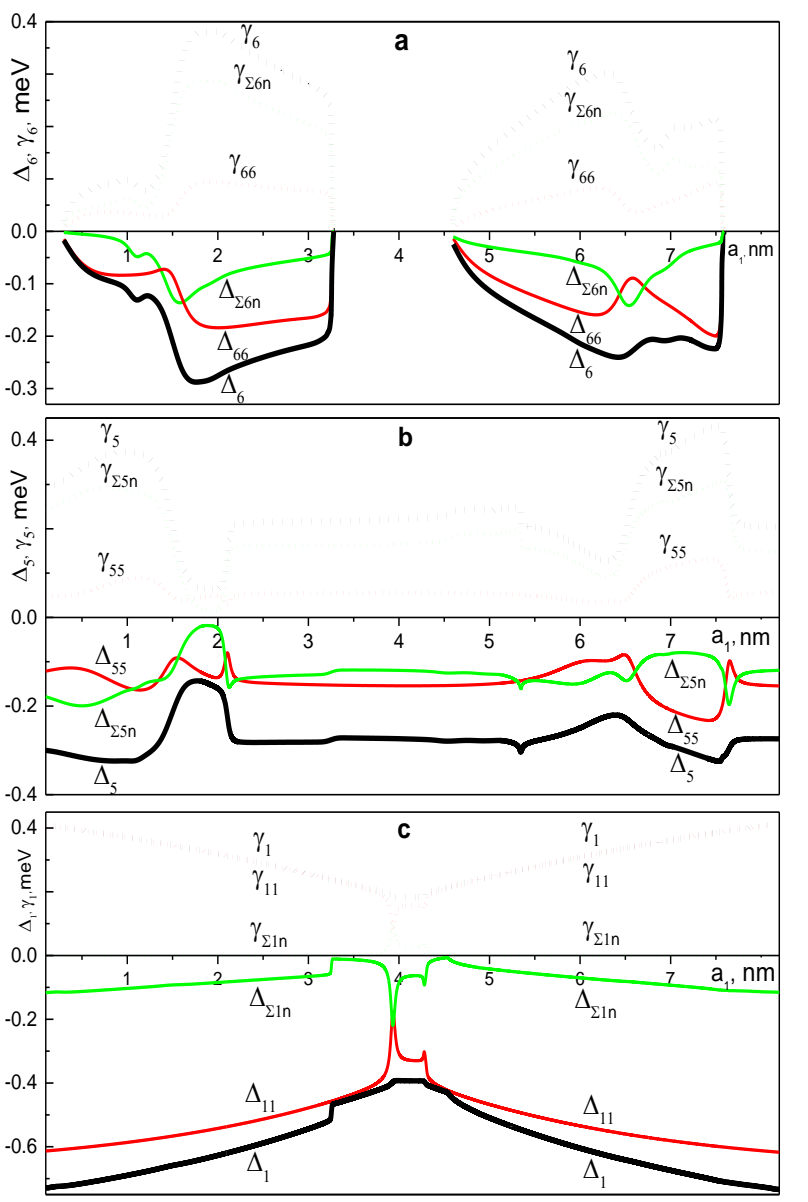

Fig. 3 - Dependences on $a_{1}$ of the total shifts $\left(\Delta_{n}\right)$ and decays $\left(\gamma_{n}\right)$ of electron operating states $(n=1,5,6)$, as well as their components $\left(\Delta_{n n}, \gamma_{n n}, \Delta_{\Sigma n n^{\prime}}, \gamma_{\Sigma n n^{\prime}}\right)$ caused by intralevel and interlevel interactions in the cascade of far-IR QCD at room temperature $(T=300 \mathrm{~K})$

In Fig. 3, the dependences on $a_{1}$ of the total shifts $\left(\Delta_{n}\right)$ and decays $\left(\gamma_{n}\right)$ of electron operating states $(n=$ $1,5,6)$ as well as their partial components due to intralevel $\left(\Delta_{n n}, \gamma_{n n}\right)$ and interlevel $\left(\Delta_{\Sigma n n^{\prime}}, \gamma_{\Sigma n n^{\prime}}\right)$ interactions at room temperature are presented for example. Fig. 3 shows that in the entire range of $a_{1}$ variation, except for small areas where energy levels anticross (Fig. 2a), shifts due to intralevel interaction dominate over shifts due to interlevel one. As for the decays of operating states, the hierarchy of their partial components for the ground and excited states is different. So, for the ground state (Fig. 3c), intralevel interaction causes a greater decay than interlevel interaction with all excited states. For excited states (Fig. 3a, b), on the contrary, decays due to the interlevel interactions predominate.

Table 1 shows the electron energies $\left(E_{n}\right)$ unrenormalized by the interaction with phonons, total shifts
$\left(\Delta_{n}\right)$ and decays $\left(\gamma_{n}\right)$ of all electron states due to electron-phonon interaction at cryogenic and room temperatures in QCD cascade with an optimized design of the two-well active region $\left(a_{1}=6.5 \mathrm{~nm}, a_{2}=1.7 \mathrm{~nm}\right)$ [18].

Table 1 - Energies $\left(E_{n}\right)$, total shifts $\left(\Delta_{n}\right)$ and decays $\left(\gamma_{n}\right)$ of electron states in the cascade of far-IR QCD at cryogenic $(T=0 \mathrm{~K})$ and room $(T=300 \mathrm{~K})$ temperatures

\begin{tabular}{|c|c|c|c|c|c|c|}
\hline \multirow{2}{*}{$n$} & \multicolumn{3}{|c|}{$T=0 \mathrm{~K}$} & \multicolumn{3}{c|}{$T=300 \mathrm{~K}$} \\
\cline { 2 - 7 } & $E_{n}, \mathrm{meV}$ & $\Delta_{n}, \mathrm{meV}$ & $\gamma_{n}, \mathrm{meV}$ & $E_{n}, \mathrm{meV}$ & $\Delta_{n}, \mathrm{meV}$ & $\gamma_{n}, \mathrm{meV}$ \\
\hline 1 & 57.79 & -0.43 & 0 & 56.21 & -0.64 & 0.34 \\
\hline 2 & 94.51 & -0.25 & $2.3 \cdot 10^{-8}$ & 90.72 & -0.39 & 0.18 \\
\hline 3 & 131.01 & -0.22 & 0.06 & 125.18 & -0.33 & 0.11 \\
\hline 4 & 167.80 & -0.19 & 0.08 & 160.26 & -0.29 & 0.09 \\
\hline 5 & 198.60 & -0.15 & 0.08 & 189.95 & -0.23 & 0.19 \\
\hline 6 & 209.38 & -0.16 & 0.11 & 201.87 & -0.24 & 0.27 \\
\hline
\end{tabular}

The values of energies, shifts and decays, presented in Table 1, make it possible to reveal the role of electron-phonon interaction and temperature dependences of the nanostructure physical parameters in the renormalization of the QCD spectral characteristics.

Calculations have shown that at $T=0 \mathrm{~K}$, the electron-phonon interaction weakly shifts QCD absorption peaks towards high energies $\left(\Delta_{15}=\Delta_{5}-\Delta_{1}=0.27 \mathrm{meV}\right.$, $\left.\Delta_{16}=\Delta_{6}-\Delta_{1}=0.26 \mathrm{meV}\right)$ and expands them $\left(\gamma_{15}=\gamma_{1}+\gamma_{5}=0.08 \mathrm{meV}, \quad \gamma_{16}=\gamma_{1}+\gamma_{6}=0.11 \mathrm{meV}\right)$. Two peaks of $\mathrm{QCD}$ absorption at $T=0 \mathrm{~K}$ correspond to the following energies renormalized by virtual confined phonons: $\quad E_{15}=E_{5}-E_{1}+\Delta_{15}=141.1 \mathrm{meV} \quad$ and $E_{16}=E_{6}-E_{1}+\Delta_{16}=151.9 \mathrm{meV}$.

At room temperature, interaction with real confined phonons leads to a stronger blue shift of both absorption peaks $\left(\Delta_{15}=0.41 \mathrm{meV}, \Delta_{16}=0.40 \mathrm{meV}\right)$ and their expansion $\left(\gamma_{15}=0.53 \mathrm{meV}, \gamma_{16}=0.60 \mathrm{meV}\right)$.

Note that with an increase in temperature, the band gaps of the nanolayers decrease and, as a consequence, the heights of potential barriers decrease too. This leads to a low-energy shift of the QCD absorption band, the magnitude of which, due to the weakness of electron-phonon interaction, exceeds the shift caused by the interaction with phonons. Calculations have shown that the energies of QCD absorption peaks at $T=300 \mathrm{~K}$ are $E_{15}=134.2 \mathrm{meV}$ and $E_{16}=146.1 \mathrm{meV}$.

Thus, an increase in temperature from cryogenic to room temperature leads to a redshift of QCD absorption peaks and their broadening, which agrees with the experimental results [17].

\section{CONCLUSIONS}

The theory of the interaction of electrons with confined phonons in a multilayer QCD cascade has been developed within the models of rectangular potentials, coordinate-dependent effective masses, and dielectric continuum. The electron spectra renormalized by the interaction with phonons are calculated by the temperature Green's functions method. The partial contributions of various mechanisms of electron-phonon interaction to the shifts and decays of electron states are investigated depending on the configuration of the two-well active region of the far-IR QCD cascade and temperature.

It is found that, due to the weakness of the electronphonon interaction, the effect of confined phonons on the 
temperature renormalization of the QCD spectral characteristics is less than the changes caused by the temperature dependence of the nanosystem potential barrier heights. It is shown that, in accordance with experiment, as the temperature increases, the QCD absorption peaks shift towards lower energies and broaden.

\title{
REFERENCES
}

1. A.P. Ravikumar, J. De Jesus, M.C. Tamargo, C.F. Gmachl, Appl. Phys. Lett. 107, 141105 (2015).

2. P. Reininger, T. Zederbauer, B. Schwarz, H. Detz, D. MacFarland, A. M. Andrews, W. Schrenk, G. Strasser, Appl. Phys. Lett. 107, 081107 (2015).

3. B. Schwarz, P. Reininger, A. Harrer, D. MacFarland, H. Detz, A.M. Andrews, W. Schrenk, G. Strasser, Appl. Phys. Lett. 111, 061107 (2017).

4. J. Liu, Y. Zhou, S. Zhai, F. Liu, S. Liu, J. Zhang, N. Zhuo, L. Wang, Z. Wang, Semicond. Sci. Technol. 33, 125016 (2018).

5. J. Huang, D. Guo, Z. Deng, W. Chen, H. Liu, J. Wu, B. Chen, J Light. Technol. 36, 4033 (2018).

6. X. Zhou, N. Li, W. Lu, Chin. Phys. B. 28, 027801 (2019).

7. A. Kolek, G. Hałdaś, M. Bugajski, K. Pierściński, P. Gutowski, IEEE J. Sel. Top. Quantum Electron. 21, 1200110 (2015).

8. A. Bhouri, A. Rached, J.-L. Lazzari, J. Phys. D: Appl. Phys. 48, 385102 (2015).

9. D. Botez, C.-C. Chang, L. J. Mawst, J. Phys. D: Appl. Phys. 49, 043001 (2016).

10. L. Cerutti, A. Vicet, E. Tournié, Woodhead Publishing, 91 (2020).

11. J.G. Zhu, S.L. Ban, Eur. Phys. J. B. 85 No140 (2012).

12. L. Zhang, J.J. Shi, X-L. Liu, Superlattices Microstruct. 83, 131 (2015)

13. C. Tang, J. Shi, Physica E Low Dimens. Syst. Nanostruct. 69 , 96 (2015).

14. C. Tang, Y. Lan, M. Dutta, M.A. Stroscio, J. Shi, IEEE J. Quantum Electron, 52, 4400108 (2016).

15. P. Harrison, A. Valavanis, Quantum Wells, Wires and Dots: Theoretical and Computational Physics of Semiconductor Nanostructures, 624 (4th Ed.) (Wiley: 2016).

16. M.V. Tkach, Ju.O. Seti, Y.B. Grynyshyn, O.M. Voitsekhivska, Acta Phys. Pol. A 128, 343 (2015).

17. L. Li, X. Zhou, Z. Tang, Y. Zhou, Y. Zheng, N. Li, P. Chen, Z. Li, W. Lu, J. Phys. D: Appl. Phys, 51, No37 (2018).

18. Ju.O. Seti, M.V. Tkach, E.Ju. Vereshko, O.M. Voitsekhivska, Math. Model. Comput, 7, 186 (2020).

\section{Вплив обмежених фононів на температурне перенормування спектральних характеристик квантового каскадного детектора далекого інфрачервоного діапазону}

\author{
Ю.О. Сеті, М.В. Ткач, Є.Ю. Верешко \\ Чернівецький національний університет імені Ю. Федьковича, вул. Коцюбинського, 2, \\ 58012 Чернівці, Україна
}

\begin{abstract}
У моделі прямокутних потенщіалів та координатно-залежних ефективних мас з урахуванням непараболічності зони провідності для електронів та ізотропного діелектричного континууму для оптичних обмежених фононів розвинена теорія електрон-фононної взаемодії у окремому каскаді широкосмугового квантового каскадного детектора далекого інфрачервоного діапазону. У однофононному наближенні отримано масовий оператор електрон-фононної взаємодії. Методом температурних функцій Гріна виконані розрахунки повних зміщень та затухань усіх електронних станів каскаду. Досліджено ієрархію різних механізмів електрон-фононної взаємодії у перенормуванні спектральних параметрів електронних станів у залежності від геометричного дизайну двоямної активної зони каскаду як при кріогенній, так і при кімнатній температурі. Показано, що незалежно від температури зміщення енергій електронних станів, викликані внутрирівневою взаемодією з обмеженими фононами, переважають над зміщеннями при сумарній міжрівневій взаемодії. Затухання основного стану при кріогенній температурі відсутне. При скінченній температурі внутрирівнева взаемодія основного стану за участю обмежених фононів викликае більше затухання ніж сумарна міжрівнева взаемодія. Для збуджених станів, навпаки, переважають затухання, викликані сумарною міжрівневою взаємодією. Встановлено, що з підвищенням температури електрон-фононна взаємодія приводить до розширення та слабкого високоенергетичного зміщення смуги поглинання детектора, а температурна зміна фізичних параметрів - до значного низькоенергетичного зміщення. Це пояснюе червоне зміщення смуги поглинання квантового каскадного детектора при зростанні температури, яке часто спостерігається на експерименті.
\end{abstract}

Ключові слова: Наносистема, Електрон, Фонон, Квантовий каскадний детектор, Функція Гріна. 